\title{
MARKETING ACTIVITIES OF HEALTH CARE ORGANIZATIONS AND PATIENT SAFETY
}

doi: $\quad 10.2478 /$ czoto-2019-0108

Date of submission of the article to the Editor: 28/11/2018

Date of acceptance of the article by the Editor: 12/01/2019

Agata Krukowska-Miler - orcid id: 0000-0002-5881-2007

Czestochowa University of Technology, Poland, agata.krukowska-miler@wz.pcz.pl

Abstract: The main goal of this publication is to show the areas where patients and marketing activities of health care organizations overlap. It shows regulations which ensure safety of a patient, and presents a path model for supporting patients in case some regularities stemming from the above mentioned contact points arise.

Keywords: health care organizations, marketing, patients, safety

\section{INTRODUCTION}

The systemic transformation in health care and the formation of the free market of medical services began in Poland in 1991 (DZ.U. 1991, No 91, item 48). In 1995, the possibility of contracting health services was introduced, which resulted in the creation of independent units. In 2003, 17 health insurance funds were transformed into the National Health Fund (NFZ). The reform assumptions concerning this change in 2004 were challenged before the Constitutional Tribunal and in 2005 were reformed. The commercialization of independent public healthcare facilities has been progressing. It was implemented in 2011 with the Act on Medical Activity (Dz.U. 2011, No. 12, item 654). Further legislative changes were aimed at reducing the waiting time for health services, retrofitting basic health care and centralizing the system (Rogala et al., 2014).

The subject of the article is not only the access to a primary care physician or specialist, but also factors affecting the quality of the service delivery, shaping the level of satisfaction of the beneficiaries. These factors are; the way the patient is treated, the quality of the information provided, the time and attention devoted to the patient by the doctor, the safety and availability of health services (Kiełbasa et al., 2015). Therefore, the use of marketing activities in health care seems necessary. However, the specificity of health services and external regulations introduce many limitations in this respect. A patient entrusts the health service with the most valuable thing, that is the patient's health and life, the trust requires that health care providers apply special safety rules and to prevent possible errors that may occur. The main goal of this publication is to show the fields of contact between patients and marketing activities of health care organizations. Additionally it is analyze possible dangers 
during do marketing and to show patients the best practices for contacting the health care organization and its marketing activity, and to show how a patient may contribute to the occurrence of errors. The possible path scenarios are discussed in the path model example.

\section{THE SPECIFICITY OF MARKETING ACTIVITIES ON THE HEALTH SERVICES MARKET}

At the moment, the use of marketing in business, including services, may be considered as being desirable. This claim can also be applied to health services. Ph. Kotler, G. Armstrong, J. Saunders, and V. Wong define marketing as follows: "Marketing - a social and management process through which individuals and groups gain what they need and want, through the creation and mutual exchange of products and values." (Kotler et al., 2002). This approach fits the specificity of the health services sector. Marketing activities in this sector are also influenced by the specificity of health services (Hołub, 2001; Bukowska-Piestrzyńska, 2009):

- This is a psychologically complex process.

- The stress that it still accompanying patients.

- Health service requires a constant interaction of the physician with the patient, therefore the attitude of the physician to the patient is of fundamental importance in terms of creating the image of the institution.

- The provision of health services is based on expert knowledge. The patient does not know what the use of complicated tools is, and they do not understand the terms used by the physician, which increases the need to build trust in the physician and facility.

- Putting the patient into the hands of a physician means understanding the patient's needs. The patient expects explanations and communication. Therefore, the physician provides not only an appropriate health service but is also required to communicate well with the patient and give as much attention as possible.

- Physicians are not always able to fully satisfy their clients.

- Physicians have little opportunity to differentiate the services they offer.

- The quality of health service depends on the physician, and the patient.

- Patients basically do not judge the technical quality of the service provided.

Looking at the above statements, it can be presumed that the expectations of patients are shaped to a large extent by previous experiences, opinions of friends, and information provided. Product - the health service is immeasurable and its perception is different in different patients (Maciąg and Sakowska, 2006; Iheanacho, 1999).

It is indisputable that in healthcare profit maximization is not the basic and only criterion of action, and physicians are not always limited by market demand (they largely shape it) and usually do not affect the price of benefits (Kowalska, 2005). Therefore, in the health services sector, the market mechanism does not ensure an effective allocation of resources. However, it should be remembered that studies of economic systems indicate a greater efficiency of the market economy, which is based on the private sector. Competition between various health care providers leads to solutions that may reduce production costs and improve the quality of offered goods and services (Buzowska, 2008; Wiercińska, 2016).

The essence of healthcare marketing is focusing on the processes of providing health services, determining pro-quality needs of patients and the implementation of tools and techniques that shape their repetitive quality. As stated by Mruk (2009), "The 
health zone belongs to areas with greater legal and administrative regulation, which to some extent limits the scope of marketing activities." In the same way, the beliefs of doctors and employees in the health sector fall under the scope of marketing activities. Also, ethical principles can be factors limiting the application of marketing rules. Therefore, comprehensive marketing management in health care organizations consists in undertaking managerial actions and decisions in relation to (important) elements and their implementation in practical activities (Andruszkiewicz 2007; Bober and Majchrzak-Lepczyk, 2015; Radulescu and Cetina, 2011).

For the purpose of these considerations, the marketing activities of the health care organization include marketing-mix activities in services consisting of product, price, distribution, promotion and people (personnel) related to the activities before, during and after patient service in a treatment facility. These activities are shown schematically in Figure 1.

\begin{tabular}{|c|c|c|}
\hline \multirow[b]{2}{*}{ 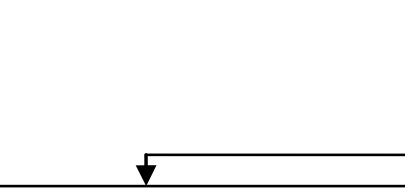 } & Patient service & \\
\hline & $\frac{1}{v}$ & 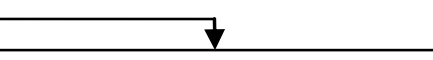 \\
\hline $\begin{array}{l}\frac{\text { Elements before the }}{\text { transaction }} \\
- \text { Mission in writing and } \\
\text { customer service } \\
\text { policy. } \\
- \text { Popularizing } \\
\text { missions and policies } \\
\text { among clients. } \\
- \text { Service objectives (in } \\
\text { writing). } \\
- \text { Processes supporting } \\
\text { goals. } \\
- \text { People and } \\
\text { structures supporting } \\
\text { goals. } \\
-\quad \text { Technical } \\
\text { background. } \\
- \text { Providing the } \\
\text { customer with a good } \\
\text { quality service. }\end{array}$ & $\begin{array}{l}\text { Elements of the } \\
\text { transaction } \\
- \text { Adaptation to } \\
\text { demand patterns. } \\
- \text { Time. } \\
- \text { Service range. } \\
- \text { The right product. } \\
- \text { Ancillary services. } \\
- \text { Environment } \\
\text { (mood). } \\
- \text { Settlements. } \\
- \text { Presentations. } \\
- \text { Convenient sale. }\end{array}$ & $\begin{array}{l}\text { Elements after the } \\
\text { transaction } \\
- \text { Guarantees. } \\
- \text { Complaints handling. } \\
- \text { Repairs and } \\
\text { compensation. } \\
\text { - Quality control. } \\
- \text { Scheme of services to } \\
\text { correct errors. } \\
-\quad \text { Dispelling fears after } \\
\text { purchase. } \\
- \text { Cross selling. } \\
- \text { Direct marketing. } \\
- \text { Clubs of "regular } \\
\text { customers". } \\
- \text { Promotional offer during } \\
\text { reduced demand. }\end{array}$ \\
\hline
\end{tabular}

Source: (Furtak, 2003).

Fig. 1. Elements of patient service

These are the elements that appear most frequently with different ranges in health care organizations. In addition, to refining and improving the quality of the patient during an operation, these elements must be carefully considered. It is necessary to estimate the frequency with which specific groups of patients will use a given service: whether it is a chronic disease requiring constant visits to a physician or incidental use of a health care organization, the time is needed to perform a given service. It is desirable to know the patient's expectations in this regard. 


\section{MARKETING ACTIVITIES AND PATIENT SAFETY}

Based on the surveys carried out by health care organizations, medical staff, patients, over many years, from 2009 up to now, it is possible to create a model of patient service along with marketing activities. In addition, areas that are potentially dangerous can be shown. For better clarity the proposed schemes have been divided into three depending on the moment of patient service, i.e.:

- marketing scheme before patient service,

- a marketing scheme in the course of patient service,

- marketing scheme after patient service.

The elements of contact with the patient were applied to these diagrams and the possible threats that may appear during the operation were indicated (Fig. 2).

\section{Management Marketing activities Threats decisions}

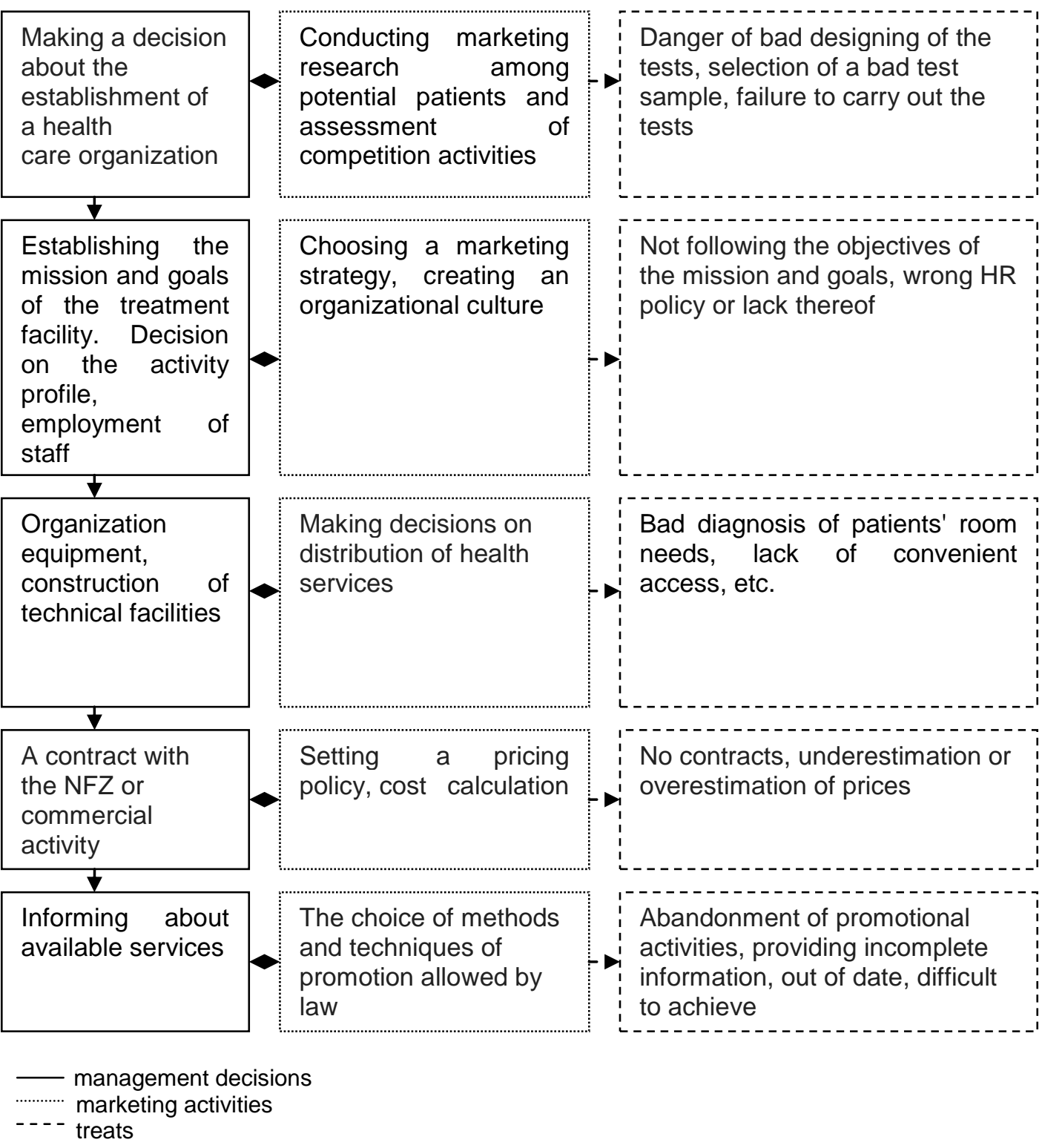

Fig. 2. Scheme of marketing and management activities before patient service and threats resulting from them 
As can be seen in Figure 2, problems may appear at the very beginning of the decision to start operations. The main threat here is the lack of market research and its needs. This may result in a mismatch of health services to the actual needs of patients. Lack of coherent goals and missions and not informing staff about them are frequent mistakes made by the managers of medical institutions. Making decisions related to personnel policy directly affects the image of the health care organization. Poorly trained staff may provide incorrect information to patients. Health care workers may treat patients badly. The lack of recognized specialists also affects the image of the institution and the treatment of patients. Distribution decisions that are made before the start of a service activity may also affect the overall operations of a healthcare facility. Bad location, the number of competing outlets in an area, the lack of convenient access are real threats to distribution. Finally, the pricing policy often determines competitiveness. The possibility of obtaining contracts with the NFZ, setting prices for commercial services payable by patients directly, poses a risk of underestimating costs and may result in an overestimation of prices (of commercial services) and outflow of patients to the competition.

The next scheme (Fig. 3) shows possible threats occurring throughout the patient's health care process. The problems presented in the flow diagram come from the literature of the subject. The process of service and communication during this process has been described by authors such as Rogoziński and BukowskaPiestrzyńska, who state that: the task of the staff is to communicate with patients in an accurate and clear way. Such communication should be based on the following principles (Rogoziński, 2000):

- all the activities should aim at the most diligent execution of the order so that the effect is consistent with the expectations of the patient - the client;

- deviations from the arrangements require the patient's acceptance;

- immediate response to any deficiencies;

- compliance to the adopted implementation schedule and its timely completion;

- comprehensive service from registering a patient, through carrying out the treatment, checking the compliance of his performance with the patient's expectations for possible complaints and further conduct.

Bukowska-Piestrzyńska (2007) recommended the following communication principles:

- provide information on alternative services;

- advise on what service is most appropriate for a given patient;

- draw the patient's attention to the unique features of a given medical service;

- provide the patient with general knowledge about the services offered and information on their benefits;

- train patients in the field of preventive and health hygiene (further monitor them, remind about inspection visits and tests);

- encourage the client/patient to provide feedback (Bui et al., 2007).

Fig. 4 shows a diagram of marketing activities after patient service and the resulting risks. This flow chart shows that the biggest problems may result in improper training of personnel who do not see the need to ensure that a patient wishes to remain a client of the health care provider. Patients after health services are often left alone, they are not reminded of visits and are not invited for follow-up visits. The use of existing databases to remind patients about visits, the need to extend prescriptions, etc., can be helpful in further monitoring. 
Management decisions
Marketing activities

Extending, reducing working hours, hours and ways to access physicians

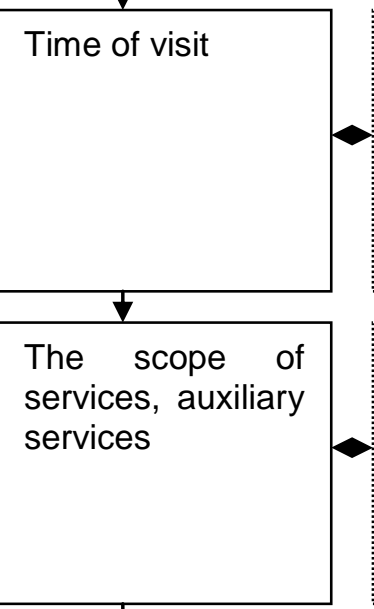

\begin{tabular}{|l|}
\hline \multicolumn{1}{|c|}{$\boldsymbol{\text { Environment, }}$} \\
mood \\
registration, \\
waiting room, \\
office, other \\
rooms
\end{tabular}
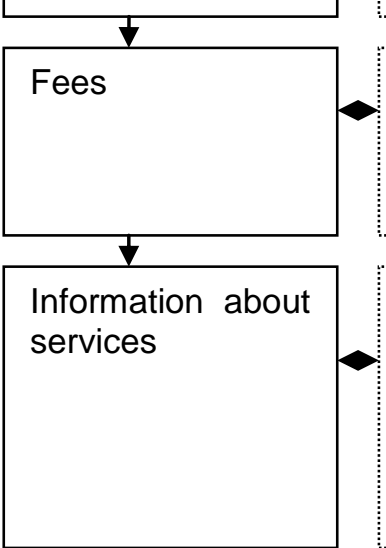

Creating a scheme of dealing with patients

Raising the standards of quality of health services, furnishing cabinets

Threats

Danger of improper time scheduling, too long waiting for the patient to visit

Too short time of providing health services may result in inaccurate service, too high a single employee's load - risk of errors, lack of satisfaction of patients

A badly designed patient service process from the moment you enter the facility until you leave it. Lack of staff training. The staff does not identify with the treatment facility

No real patient needs defined, no intimate, no equipment, technical defects temperature availability, comfort of places for patients

Price policy. Possibility of making payments

No contracts, underestimation or overestimation of prices. Lack of convenient payment options mobile banking transfers, lending

Placing information boards, personnel IDs, premises designation
Weak markings, no markings, lack of personnel identification introduces uncertainty and chaos among patients, may result in mistakes, dissatisfaction

\footnotetext{
- management decisions marketing activities

- - - treats
}

Fig 3. Scheme of marketing and management activities in the course of patient service and threats resulting from them

Satisfied patients become ambassadors of the 'brand' of the health care organization, who can gain new patients and build their market position. 


\begin{tabular}{|c|c|c|}
\hline $\begin{array}{l}\text { Management } \\
\text { decisions }\end{array}$ & Marketing activities & Threats \\
\hline $\begin{array}{l}\text { Guarantees and } \\
\text { settlement of } \\
\text { complaints }\end{array}$ & $\begin{array}{l}\text { Creating a cell } \\
\text { responsible } \\
\text { handling a complaint, a } \\
\text { flow chart }\end{array}$ & $\begin{array}{l}\text { Lack of a definite scheme of } \\
\text { conduct in the event of } \\
\text { complaints appearing, } \\
\text { employees not informed }\end{array}$ \\
\hline $\begin{array}{l}\text { Monitoring of } \\
\text { patients after } \\
\text { service }\end{array}$ & $\begin{array}{l}\text { Staff training, facilities } \\
\text { for patients, creating } \\
\text { active databases }\end{array}$ & $\begin{array}{l}\text { Lack of staff training, inability to } \\
\text { use databases }\end{array}$ \\
\hline $\begin{array}{l}\text { Correction of } \\
\text { errors and } \\
\text { development }\end{array}$ & $\begin{array}{lr}\text { Conducting } & \text { permanent } \\
\text { control } & \text { tests, } \\
\text { monitoring } & \text { the } \\
\text { environment } & \end{array}$ & $\begin{array}{l}\text { No testing and monitoring of the } \\
\text { surroundings or tests carried out } \\
\text { incorrectly }\end{array}$ \\
\hline $\begin{array}{l}\text { Establishing long- } \\
\text { term contacts with } \\
\text { patients }\end{array}$ & $\begin{array}{l}\begin{array}{l}\text { Creation of prosumer } \\
\text { groups, building }\end{array} \\
\text { community of the } \\
\text { health } \\
\text { organizations, } \\
\text { conducting preventive } \\
\text { and health-related } \\
\text { activities }\end{array}$ & $\begin{array}{l}\text { Leaving patients without further } \\
\text { monitoring, failure to inform } \\
\text { patients about the development } \\
\text { of the organization and the } \\
\text { inability to focus patients in the } \\
\text { treatment facility } \\
\text { disappearance of promotional } \\
\text { activities }\end{array}$ \\
\hline
\end{tabular}

Fig. 4. Scheme of marketing and management activities after patient service and threats resulting from them

\section{CONCLUSION}

The presented issues require further research and development. However, the specificity of health services and the fact that they concern the health and life of people require a very careful approach to issues related to the marketing activity of a treatment facility. Threats may also arise from other factors. These threats are not only medical mistakes but also the omission of relevant information that can improve the quality of services. There is still an insufficient amount of marketing research related to the issues mentioned above, such research could allow the possibility to better adjust the service offered to the needs of patients, react to emerging errors in the management of the health care organizations. Other serious threats regarding the patient's contacts with an organization is the incorrect selection of personnel, lack of training in the field of health care marketing, lack of identification with the mission and goals of the organization, lack of information for employees. (Crie and Chebat, 2013) There are also technical threats such as equipment and branding. The financial aspect of health care received less consideration due to the large percentage of services contracted with the NFZ and the inability to directly influence this phenomenon. The above considerations may be extended in the future with a macro perspective as the health centre is also influenced by a number of external factors. 


\section{REFERENCES}

Andruszkiewicz, K., 2007. Strategiczne zarządzanie marketingowe w polskich przedsiębiorstwach w warunkach kryzysu. Wydawnictwo Naukowe Uniwersytetu Mikołaja Kopernika w Toruniu, Toruń.

Bober, B., Majchrzak-Lepczyk, J., 2015. Rola oraz zadania marketingu w procesie świadczenia usług w szpitalach publicznych. Handel Wewnętrzny, 5, 358, 62-80.

Bui, Th., Primack, B.A., Fertman, C.I., 2007. Social marketing meets health literacy: innovative improvement of health care providers' comfort with patient interaction. 68, 1, 3-9, https://doi.org/10.1016/j.pec.2007.02.009 (18.11.2018)

Bukowska-Piestrzyńska, A., 2009, Marketing usług zdrowotnych Od budowania wizerunku placówki do zadowolenia klientów. CeDeWu, Warszawa.

Buzowska, B., 2008. „Urynkowiony” system usług medycznych - argumenty za i przeciw. „Zdrowie Publiczne”, 118, 2.

Crie, D., Chebat J-C., 2013. Health marketing: Toward an integrative perspective. Journal of Bussiness Research, 66. https://doi.org/10.1016/j.jbusres.2012.09.002.

Furtak, R., 2003. Marketing partnerski na rynku usług. PWE, Warszawa.

Holub, J., 2001. Kierunki rozwoju marketingu na rynku usług medycznych. Przegląd Organizacji, 6.

Iheanacho, M., 1999. Marketing health care, Current Surgery, 56, 1-2, 80-81. https://doi.org/10.1016/S0149-7944(99)00030-6.

Kiełbasa, S., Kaźmierczak, N., Patryn, R., Niedzielski A., 2015. Promocja marketingowa usług medycznych świadczonych przez lekarzy - analiza możliwości i ograniczeń. Medycyna Ogólna i Nauki o Zdrowiu, 21, 2, 198-203,

Kotler, Ph., Armstrong G., Saunders J., Wong V., 2002. Marketing - podręcznik europejski. PWE, Warszawa.

Kowalska, K., 2005. Racjonowanie usług medycznych - spojrzenie ekonomisty. Diametros, 5.

Maciąg, A., Sakowska, I., 2006. Rola i prawa pacjenta w obszarze jakości usług zdrowotnych. Studia i Materiały - Wydział Zarządzania UW, http://www.sim.wz.uw.edu.pl/sites/default/files/artykuly/sim_2006_1_maciag_sako wska.pdf (18.11.2018).

Mruk, H., 2009. Marketing gabinetów lekarskich na rynku usług zdrowotnych. Wolters Kluwer Polska, Warszawa.

Radulescu, V., Cetina, I., 2011. The impact of health care consumer education on marketing strategies of health services organization. Procedia - Social and Behavioral Sciences, 15, 388-393, https://doi.org/10.1016/j.sbspro.2011.03.109.

Rogala, M., Badora-Musiał, K., Kowalska, I., Mokrzycka, A., 2014. Rola działań marketingowych $w$ zarządzaniu podmiotem leczniczym na przykładzie Uniwersyteckiego Szpitala Dziecięcego w Krakowie. Zdrowie Publiczne i Zarządzanie, 12, 2, 163-174. DOI: 10.4467/208426270Z.14.018.3110.

Rogoziński, K., 2000. Usługi rynkowe. Wydawnictwo AE w Poznaniu, Poznań.

Wiercińska, A., 2016. Specyfika rynku usług zdrowotnych. www.researchgate.net/publication/295667557_Specyfika_rynku_uslug_zdrowotny ch (20.11.2018).

Ustawa o działalności leczniczej Dz.U. 2011, Nr 12, poz. 654.; Ustawa o zakładach opieki zdrowotnej Dz.U. $1991 \mathrm{Nr} 91$ poz. 408, z późniejszymi zmianami. 